\title{
RUMAH JUNTI \\ DI DESA JUNTIKEBON KECAMATAN JUNTINMUAT KABUPATEN INDRAMAYU
}

\author{
House of Juntikebon, district of Juntinyuat, Regency of Indramayu \\ Oleh Ria Intani T. \\ Balai Pelestarian Sejarah dan Nilai Tradisional Bandung \\ Jln. Cinambo No. 136 Ujungberung Bandung \\ Email: ria_intani@yahoo.com
}

\begin{abstract}
Abstrak
Desa Juntikebon Kecamatan Juntinyuat berada di Kabupaten Indramayu. Desa Juntikebon memiliki kekhasan dalam hal arsitektur rumah tinggal. Rumah tinggal penduduk asli Juntikebon berarsitektur tradisional. Bentuk rumahnya limasan dan srotongan dengan bahannya dari kayu dan bambu. Rumah limasan ditandai dengan bentuk atap berupa jajaran genjang, sedang rumah srotongan ditandai dengan bentuk atap segi tiga. Orang Junti (penggalan dari Juntikebon) rmenyebut rumah sejenis itu dengan rumah limasan dan srotongan. Orang di luar kecamatan sering menyebutnya dengan rumah Junti. Rumah limasan/srotongan/Junti menggunakan bahan-bahan yang pada umumnya diambil dari kebun sendiri. Selebihnya adalah dibeli dari lingkungan sekitar. Pekerja intinya adalah tukang bangunan dan tukang anyam, selebihnya adalah bantuan tenaga dari para tetangga. Dengan kondisi tenaga kerja yang demikian, pada umumnya membangun rumah limasan/srotongan/Junti selesai dalam kisaran waktu tiga minggu. Rumah limasan/srotongan/Junti dibangun dengan beradaptasi pada alam dan iklim setempat. Segala makna yang melekat pada bangunan rumah, sejatinya menggambarkan keyakinan serta pengharapan di dalam menjalani kehidupan.
\end{abstract}

Kata kunci: arsitektur tradisional, rumah tinggal, adaptasi dengan alam.

\section{Abstract}

Desa/village Juntikebon, Kecamatan/district Juntinyuat (Kabupaten/regency Indramayu) has a distinctive architecture of traditional house, called limasan and srotongan. People outside the village call it rumah Junti (house of Junti). The uniqueness of this architecture is in its adaptive design to nature and weather, and every elements of the house depicts their faith and hopes in their life. Materials for building the limasan and srotongan are generally taken from their own gardens. Only some small amount are purchased from the surrounding area. The main workers are masons and artisan spesiallising in weaving bamboo wall, and the neighbours do the rest.

Keywords: traditional architecture, houses, being adaptive to the nature. 


\section{A. PENDAHULUAN}

Sejak manusia terlahir ke dunia, sejak itulah kebudayaan lahir. Manusia terlahir dengan dilengkapi panca indera, salah satunya adalah kulit. Melalui kulitnya manusia bisa merasakan panas dan dinginnya cuaca, serta rasa sakit. Berlanjutlah kemudian manusia merasa membutuhkan "kulit yang kedua" untuk melindungi tubuhnya, tak lain adalah pakaian sesuai pada zamannya. Seiring dengan perkembangan mata pencaharian, selanjutnya manusia tinggal menetap. Dibutuhkanlah kemudian "kulit yang ketiga" yang tak lain adalah bangunan untuk tempat tinggal. Pada zamannya, gua menjadi pilihan untuk tempat tinggal. Seiring dengan meningkatnya pengetahuan dan pemanfaatan hubungan antara manusia, lingkungan, dan alamnya, terciptalah kemudian model bangunan yang secara prinsipil dilatari oleh model gua.

Berdasarkan fungsinya, bangunan dapat dibedakan menjadi dua jenis yakni bangunan sakral dan profan. Bangunan untuk musyawarah atau kegiatan ritual, untuk ibadah, dan untuk menyimpan padi, termasuk pada bangunan sakral. Adapun bangunan untuk tempat tinggal termasuk pada bangunan profan.

Tradisi membangun merupakan sebuah tradisi berarsitektur. Kalau wilayah Nusantara memiliki lebih kurang 500 suku bangsa, bukan tidak mungkin ada lebih kurang 500 bentuk arsitektur. Arsitektur pada suku-suku bangsa selalu berhubungan dengan kepercayaan yang dianut suku bangsa yang bersangkutan, iklim, kondisi alam, serta sistem mata pencaharian masyarakatnya.

Menurut Purwestri, Nadia (2009:1), walaupun tiap-tiap suku bangsa mempunyai bentuk arsitektur yang berbeda-beda, namun demikian tradisi berarsitekturnya mempunyai kesamaan ciri. Kesamaannya adalah: bahwa kepercayaan yang dianut oleh suatu kelompok masyarakat mempunyai peranan yang sangat penting dalam tradisi vernakular 'membangun rumah'; Arsitektur di tiap suku bangsa beradaptasi dengan alam dan iklim setempat; Arsitektur tradisional memiliki bentuk atap yang dominan; Arsitektur tradisional memiliki konstruksi kayu; Tradisi membangun rumah di Indonesia terbuat dari bahan-bahan yang ada di alam sekitar; dan, memiliki fondasi di atas tanah. Hal ini umum terjadi karena rumah tradisional di Indonesia berbahan dari alam sekitar seperti rumbia, kayu, dan bambu. Bahan-bahan tersebut rentan terhadap rayap dan karenanya tidak boleh lembab.

Tumbuh dan berkembangnya arsitektur tradisional seiring dengan pertumbuhan suatu bangsa. Tidak berlebihan kalau dikatakan bahwa arsitektur tradisional dapat memberi ciri pada suatu suku bangsa sebagai pendukung dari kebudayaan tertentu. Di zaman yang serba modern ini, tidak mudah mendapati bangunan yang berarsitektur tradisional. Apalagi untuk jenis bangunan rumah tinggal. Penyebabnya seperti dikemukakan oleh Suantika, Wayan (2009:1) bahwa bangunan-bangunan profan (termasuk rumah) dibuat dari material yang kurang kuat. Sebaliknya bangunan yang bersifat sakral biasanya dibuat dari material yang tahan lama. Selain itu, bangunan sakral sedikit mengalami perubahan disebabkan pada bangunan sakral "menempel" keyakinan akan kesucian.

Kenyataan akan minimnya tinggalan bangunan rumah berarsitektur tradisional terjadi pula di Indramayu. Meskipun demikian, ada salah satu desa yang sebagian rumah penduduknya masih berarsitektur tradisional, yakni Desa Juntikebon. Melihat jumlah rumah tradisionalnya yang sangat minim, ada kekhawatiran segera hilang dari pandangan mata. Kondisi inilah yang kemudian menggiring penulis untuk menelitinya.

Terkait dengan tulisan ini, ada tiga konsep yang digunakan sebagai rujukan yakni: konsep tentang kebudayaan, tentang arsitektur, dan tentang arsitektur tradisional. Menurut Koentjaraningrat (1990:9) kebudayaan diartikan sebagai keseluruhan gagasan dan hasil karya manusia, yang harus dibiasakannya dengan belajar, beserta keseluruhan dari hasil budi dan karyanya itu. 
Hasil dari proses budidaya manusia itu kesemuanya dimaksudkan untuk meningkatkan kualitas kehidupan yang lebih bermakna.

Selanjutnya, arsitektur diartikan sebagai ilmu dan seni membangun. Ilmu membangun adalah ilmu yang mempelajari segala pengetahuan tentang bangunan yang terikat pada perhitungan matematis yang mempunyai keterbatasan kaidah hukum alam dan teknik. Seni membangun adalah seni yang berhubungan dengan ruang, segala upaya mencapai harmoni, selaras, dan kenyamanan dalam suatu proses penciptaan atau perancangan sebuah bangunan, kelompok bangunan, dan atau suatu tata ruang lingkungan buatan, yang didasari atas kebutuhan bersama (Oesman dalam Abstraksi Tradisi Arsitektur Nusantara, 2009:3).

Adapun arsitektur tradisional merupakan suatu bangunan yang bentuk, struktur, fungsi, ragam hias, dan cara membuatnya diwariskan dari satu generasi ke generasi berikutnya, serta dapat dimanfaatkan sebagai tempat untuk melaksanakan segala aktivitas kehidupan (2009:1).

Tujuan penelitian ini adalah untuk mendapatkan dokumentasi secara tertulis tentang arsitektur tradisional rumah Junti dari mulai nama, tipologi, dan bentuk rumah; proses mendirikan rumah; fungsi bagian-bagian bangunan rumah; dan upacara yang menyertai pendirian rumah.

Wilayah penelitian di Desa Juntikebon, Kecamatan Juntinyuat, Kabupaten Indramayu. Adapun lingkup materinya adalah rumah tinggal yang tradisional. Pada bangunan rumah yang tradisional tersebut diteliti tentang: nama, tipologi, dan bentuk rumah; proses mendirikan rumah; fungsi bagian-bagian bangunan rumah; dan upacara yang menyertai pendirian rumah.

Jenis penelitian tentang rumah Junti ini adalah kualitatif. Adapun metode yang digunakan untuk mengumpulkan data, yakni: Pengamatan, mengamati secara langsung bentuk fisik dari rumah Junti beserta unsur-unsurnya; Wawancara, mewawancarai orang-orang yang dianggap menguasai permasalahan untuk mendapatkan data tentang nama, tipologi, bentuk rumah, proses mendirikan rumah, fungsi bagian-bagian bangunan rumah, dan upacara yang menyertai pendirian rumah. Wawancara dilakukan dengan menggunakan pedoman wawancara dan tanpa pedoman wawancara atau bersifat spontan; Studi kepustakaan, melengkapi data lapangan dengan menambahkan data-data yang diperoleh dari kepustakaan.

\section{B. HASIL DAN BAHASAN}

\section{Gambaran Umum Desa Juntikebon}

Desa Juntikebon berada di wilayah Kecamatan Juntinyuat Kabupaten Indramayu. Desa ini berluas 424,2 ha dan didominasi oleh pesawahan. Pusat Pemerintahan Desa Juntikebon dapat dikatakan hanya berjarak 0 $\mathrm{km}$ dari pusat Pemerintahan Kecamatan Juntinyuat. Atau, 15 menit dengan berkendaraan umum. Adapun jarak dari pusat Pemerintahan Kabupaten Indramayu berkisar $22 \mathrm{~km}$ yang bila ditempuh dengan kendaraan umum memakan waktu 45 menit.

Desa Juntikebon wilayahnya datar hingga memudahkan bagi kendaraan apa pun untuk melaluinya. Pada kurun waktu satu tahun hujan turun di desa ini selama lebih kurang 3 bulan. Ketinggian tempat 2 mdl dari permukaan laut dengan suhu ratarata harian $32^{\circ} \mathrm{C}$ menjadikan Desa Juntikebon berhawa panas.

Rumah-rumah penduduk di Desa Juntikebon letaknya berjajar mengikuti jalan kampung dengan arah rumah menghadap ke jalan kampung. Pola ini dapat tercipta oleh karena Desa Juntikebon berlahan luas sehingga tidak terdapat rumahrumah penduduk yang letaknya berdesakan tidak teratur.

Desa Juntikebon terdiri atas 2.153 kepala keluarga (KK) dengan jumlah total penduduk 7.034 orang. Jumlah tersebut terbagi atas laki-laki berjumlah 3.501 orang dan perempuan 3.533 orang. Tingkat pendidikannya sangat variatif, dari mulai tidak tamat SD/sederajat, tamat SD/sederjat, SLTP/sederajat, SLTA/sederajat, D1， D2, D3, sampai dengan S1.

Mayoritas penduduk Desa Juntikebon bermatapencaharian sebagai petani diikuti oleh buruh tani, TKI/TKW, buruh/ 
swasta, pedagang, nelayan, PNS, perajin, peternak, montir, dan dokter.

Penduduk Desa Juntikebon mayoritas beragama Islam yaitu sebanyak 6.982 orang. Adapun selebihnya beragama Kristen. Lembaga kemasyarakatan terdiri atas organisasi pemuda/pemudi, organisasi profesi (kelompok tani), majelis taklim, organisasi bapak-bapak, LKMD/sejenisnya, dan kelompok gotong royong. Lembaga adat terdiri atas bumi loka, mapag sri, baritan, dan unjungan.

Ditilik dari segi prasarana dan sarana, menunjukkan bahwa kondisi jalan desa ada yang beraspal, jalan makadam, dan jalan tanah. Prasana peribadatan yang tersedia berupa masjid sebanyak 1 buah, langgar/surau/mushola 17 buah, dan gereja 1 buah.

Pada waktu-waktu tertentu, ada harihari yang mana masyarakat melakukan aktivitas budaya yang pada zamannya dilakukan oleh para karuhun. Aktivitas budaya itu di antaranya ada upacara yang berkaitan dengan daur hidup manusia; upacara yang berkaitan dengan pengelolaan tanah pertanian seperti bumiloka dan mapag sri; upacara tolak bala seperti baritan, dan ziarah kubur seperti unjungan. Melalui upacara, tradisi gotong-royong dan silaturahmi antarwarga tetap terjaga. Di luar aktivitas budaya, gotong royong terlihat dalam acara hajatan, pada saat terjadi musibah, membangun rumah, dan lain sebagainya.

\section{Asal-usul Juntinyuat}

Di tepi Kota Indramayu sebelah utara, terdapat sebatang pohon junti yang besar, yang salah satu dahannya menjorok ke laut. Pohon ini menjadi tanda bagi para nakhoda yang datang dari Negeri Cina, Malaysia, India, Bugis, Palembang, dan lain sebagainya, bahwa Pelabuhan Muara Jati Cirebon sudah dekat.

Dikisahkan, suatu hari seorang lelaki paruh baya sedang memegang joran 'tangkal kail' di balik semak belukar. Ketika tengadah ke langit, terlihat bianglala. Tidak berapa lama, dari bianglala muncul titik-titik cahaya yang makin lama makin membesar dan menuju ke arah lelaki paruh baya itu berada. Tiba-tiba datang enam orang bidadari dan begitu menjejakkan kakinya ke bumi, langsung menuju kolam. Mereka lalu mandi, tanpa sehelai benang pun. Salah satu pakaian bidadari lalu diambil oleh lelaki itu dan disembunyikannya.

Seusai mandi, satu demi satu bidadari mengenakan pakaian, tinggallah seorang yang masih mencari-cari pakaiannya. Setelah sekian lama tidak juga diketemukan, maka bidadari itu ditinggalkan oleh teman-temannya. Ia putus asa lalu bersumpah, apabila ada yang menemukan pakaian dan dia seorang pemuda, maka akan dijadikannya suami. Begitu mendengar sumpah sang bidadari, lelaki itu keluar dari persembunyiannya. Singkat kata sang bidadari menepati janjinya namun dengan satu syarat. Syaratnya adalah, apabila mereka berumahtangga dan mempunyai anak, tidak boleh keluar kata-kata "parang" dari mulut sang suami. Bila ini dilanggar, maka putuslah hubungan suami istri.

Singkat cerita mereka dikaruniai seorang bayi yang dinamai Nyi Nawangwulan. Suatu hari anaknya sakit dan dikatakan oleh sang suami bahwa penyakit yang diderita anaknya adalah penyakit parang. Begitu sang suami mengatakan demikian, sontak menyesal karena ingat akan sumpahnya. Mau tak mau ia harus rela manakala istrinya meninggalkannya. Sebelum kepergian sang bidadari, ia meninggalkan wasiat kepada suaminya berupa selendang lokoan berwarna merah menyala. Selendang itu bisa digunakan sebagai azimat manakala ada malapetaka menimpa anaknya.

Anaknya tumbuh menjadi perawan cantik. Rumahnya yang berpagar tinggi ditambah kebun sayuran yang luas yang menjadi cikal bakal Juntikebon, membuatnya tak pernah melihat dunia luar. Suatu hari Nyi Nawangwulan memerlukan air, mencarilah ia sumber air. Sumber air itu ia dapatkan, di tempat sang ibu dan ayahnya bertemu. Selanjutnya tempat tersebut dina- 
mai Juntinyuat, diambil dari nama pohon junti yang dahannya menjorok ke laut.

Syahdan ada sebuah perahu besar dari Cina yang dinakhodai Dempu Awang berlabuh. Oleh karena kehabisan air minum, awak kapalnya diperitahkan untuk mencari air. Ditunjukkanlah oleh penduduk tempat air itu di Juntikedokan. Sepulang mengambil air, mereka dikagetkan melihat perempuan cantik di tempat itu. Berceritalah para awak kapal itu kepada sang nakhoda. Setengah tak percaya, turunlah ia dari kapal untuk mencari kebenaran cerita itu. Tanpa kesulitan, bertemulah Dempu Awang dengan Ki Gede Junti, ayah si gadis. Ia mengutarakan maksudnya untuk melamar anaknya. $\mathrm{Ki}$ Gede Junti secara halus menolak lamarannya dengan berdalih pada satu syarat. Syaratnya adalah Dempu Awang harus membakar pagar bambu yang mengelilingi rumahnya dalam satu malam. Demi mendapatkan sang putri, disanggupinya syarat itu.

Hari itu juga Dempu Awang mengumumkan kepada penduduk kalau malamnya ia akan menaburkan uang emas di sepanjang pagar bambu milik Ki Gede Junti. Penduduk diperbolehkan mengambil uang itu dengan terlebih dulu membabad pagar bambu sampai bersih. Penduduk menyambut dengan gembira.

Malam pun tiba, semalam suntuk ramai orang membabad pagar bambu sambil mengantongi uang emas. Menjelang pagi, selesailah pagar bambu itu dibabad. Ki Gede Junti resah lalu menyuruh putrinya melarikan diri ke arah timur. Dempu Awang mengetahui lalu mengejarnya dan akhirnya tertangkap. Di suatu desa ia menjadi bebondan 'diikat kaki tangannya', jadilah desa itu Desa Benda. Manakala Dempu Awang menagih janjinya, sang putri mengajukan syarat. Ia minta dibuatkan sebuah keraton dalam waktu satu malam. Menjelang pagi, keraton nyaris selesai dibuat. Sang putri minta dilepaskan ikatannya dan diantar ke pantai. Setiba di tepi pantai, sang putri membeberkan selendang wasiatnya. Sesaat muncul semburat merah, menunjukkan bahwa mentari pagi akan segera muncul. Kejadian itu membingungkan Dempu Awang, apalagi keratonnya belum selesai. Dalam kebi- ngungan Dempu Awang, sang putri melarikan diri ke arah selatan lalu dikejarlah sang putri.

Manakala sang putri nyaris tertangkap, terdengarlah suara tanpa diketahui dari mana asalnya. Suara itu mengingatkan Dempu Awang bahwa hati nurani manusia tidak akan luluh oleh mas intan berlian dan kebengisan, akan tetapi kasih sayang dan budi luhur. Mendengar suara itu, relung hati Dempu Awang mulai gusar karena sesungguhnya ia mengiyakan kebenaran suara itu. Namun demi mempertahankan harga diri, Dempu Awang malahan menantang sang empunya suara untuk keluar dan memperkenalkan diri. Keluarlah seseorang yang menamakan dirinya Syekh Bentong. Terjadilah kemudian pertempuran antara keduanya. Melihat kesaktian Syekh Bentong, ia lalu meninggalkan arena pertempuran dan lari menuju kapalnya. Sambil kapal mulai berlayar, keluarlah sumpah dari Dempu Awang. Sumpahnya adalah bahwa di hari kemudian, para remaja putri Junti akan menjadi perawan tua manakala ada yang melamar ditolak, dan badannya kaku seperti badan pria. Karena harta yang dihamburkan Dempu Awang di desa itu, maka orang Juntinyuat terkenal sebagai orang-orang kaya. Kisah asal-usul Juntinyuat ini menguatkan bahwa pengaruh Cina masuk ke Indramayu.

\section{Bentuk Rumah Junti}

Ada dua jenis rumah di Juntikebon, yakni rumah tradisional dan modern. Rumah tradisional Juntikebon disebut dengan rumah limasan dan srotongan. Orang dari luar Kecamatan Juntinyuat, sering menyebut rumah tradisional itu dengan sebutan rumah Junti, diambil dari bagian depan nama kecamatan.

Keberadaan rumah Junti dewasa ini tidak sebanyak rumah modern. Diperoleh informasi, rumah Junti mulai berkurang sejak tahun 1993-an, sejak banyaknya perempuan Junti menjadi tenaga kerja wanita (TKW) di Arab Saudi. Kepulangan mereka ke kampung halaman dengan membawa uang yang berlimpah setiap dua tahun sekali, merevolusi gaya hidup TKW 
yang bersangkutan. Salah satunya dengan merombak tempat tinggal mereka.

Tipologi bangunan rumah Junti adalah persegi panjang. Adapun bentuk atap limasan dan srotongan. Bentuk limasan ditandai dengan bagian depan dan belakang atap berbentuk jajaran genjang, sedang di samping kiri dan kanannya berbentuk segi tiga. Adapun bentuk srotongan ditandai dengan atap yang berbentuk segi tiga. Meskipun kedua badan rumah berbentuk persegi panjang, namun demikian perwujudannya berbeda. Pada rumah limasan, badannya melebar ke samping, sedang pada rumah srotongan badannya memanjang ke belakang.

\section{Gbr. 1 Rumah Srotongan}

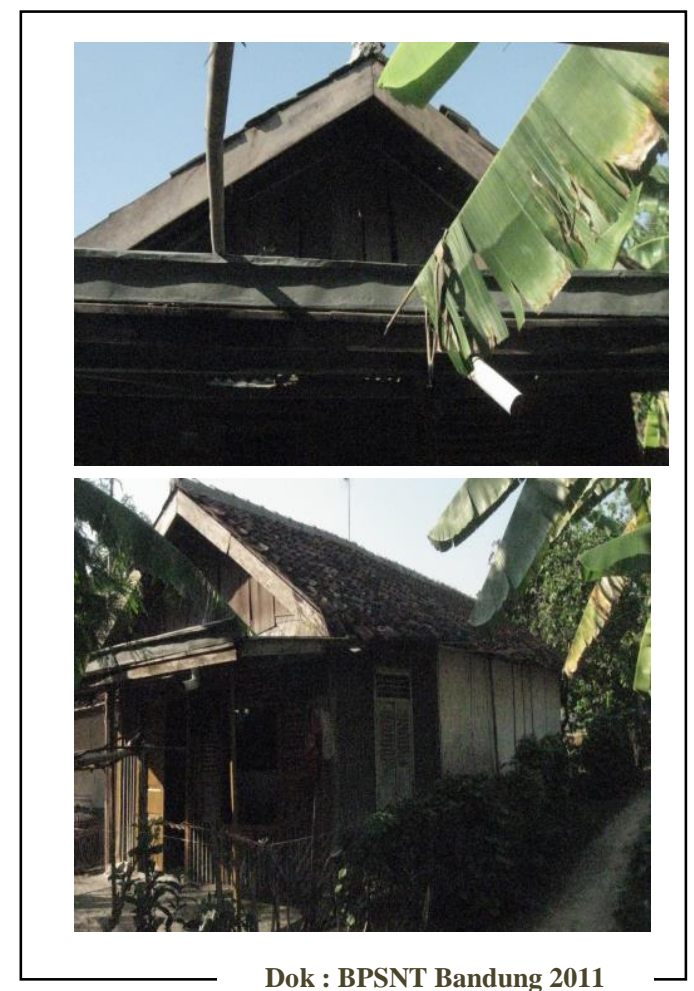

Dok : BPSNT Bandung 201

\section{Gbr. 2 Rumah Limasan}

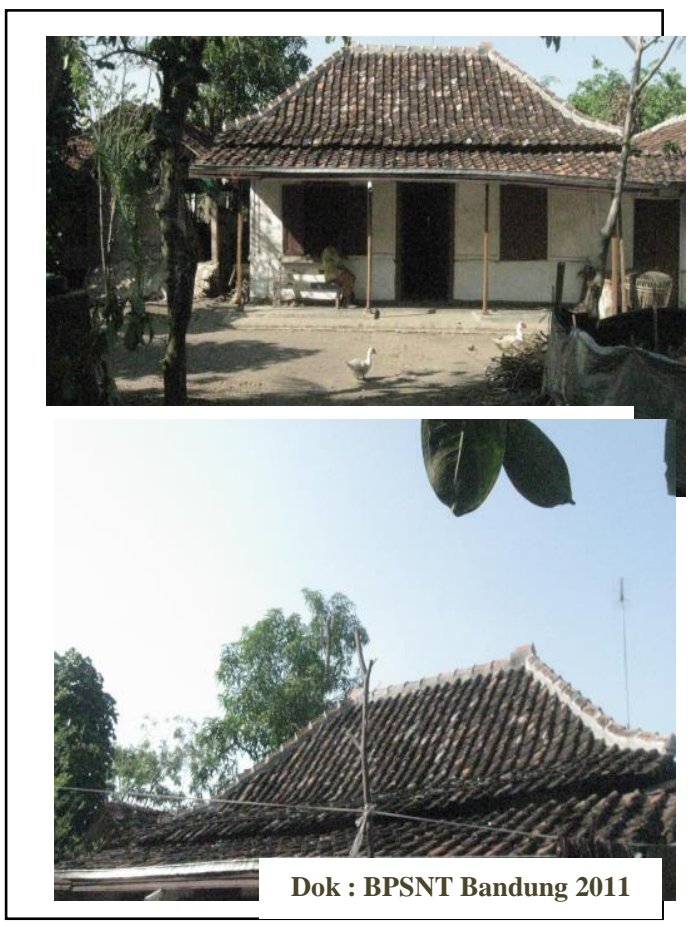

Struktur dan tata ruang rumah Junti terbagi atas ruang bagian depan, tengah, dan belakang, dan bangunan bagian atas, tengah, dan bawah. Ruang bagian depan adalah blandongan 'ruang tamu', ruang bagian tengah adalah jobong 'ruang tidur', dan ruang bagian belakang adalah pawon 'dapur' dan kulah 'kamar mandi'. Sedang bangunan bagian atas adalah atap, bagian tengah adalah saka 'tiang', dan bagian bawah adalah lantai.

Rumah Junti diperkirakan mendapat pengaruh dari Cirebon, hal ini dibuktikan dengan adanya bangunan semacam rumah Junti di Keraton Kasepuhan. Cirebon sendiri memiliki bentuk bangunan seperti itu bukan tidak mungkin karena berbagai pengaruh budaya yang masuk ke Cirebon. Model rumah Junti di Cirebon, diperkirakan mendapat pengaruh dari Demak, Lamongan, dan Jepara, oleh karena pada ketiga daerah tersebut terdapat bangunan rumah menyerupai rumah Junti. Pengaruh budaya itu dibawa oleh salah satu Wali Sanga, yakni Sunan Kudus, terkait dengan aktivitasnya dalam penyebaran agama Islam. 


\section{Proses Mendirikan Rumah}

\section{a) Tahap Persiapan}

Jauh sebelum membangun rumah, pemilik rumah akan menghitung kebutuhan yang diperlukan. Secara garis besar, kebutuhannya berkaitan dengan pengadaan bahan, ongkos membayar tukang, keperluan konsumsi selama membangun, dan acara ritual seputar rumah. Setelah itu, pemilik rumah menghubungi orang yang dianggap bisa mengetahui hari baik untuk awal membangun rumah dan persoalan lain seputar membangun rumah. Berdasarkan penentuan dari orang pintar itulah, pembangunan rumah dilakukan. Penentuan hari baik dianggap penting, oleh karena pemilik rumah berharap agar rumah yang ditempati tersebut dapat membawa rizki, memberikan rasa nyaman, dan dijauhkan dari malapetaka.

Selanjutnya, pemilik rumah menghubungi tukang yang nantinya diminta tolong untuk membangun rumahnya. Pada musim kemarau, pemilik rumah mulai mencicil pekerjaan terkait dengan penyediaan bahan. Atas petunjuk tukang, pemilik rumah memotong kayu-kayu sesuai ukuran, kemudian kayu itu dijemur, lalu dikungkum 'direndam' sekitar 6 bulan. Maksud dari menjemur dan merendam kayu itu agar kayu kuat dan tidak terkena bubuk/rinyuh.

Manakala kayu sudah melalui proses yang pertama, sebulan sebelum dilakukan pembangunan rumah, kayu disugu 'dihaluskan', dibobok 'dilubangi tanpa alat', dan dibor terlebih dahulu.

Rumah Junti terbangun dari bahan berupa genting, kayu, bambu, dan bata merah. Genting menjadi penutup atap. Kayu di antaranya menjadi rangka atap, tiang penyangga rumah, kusen pintu dan jendela, angin-angin 'lubang angin', dan roji-roji 'tralis'. Adapun bambu menjadi dinding rumah dan pagar. Sebagai lantai rumah digunakan bata merah atau bahan untuk bata merah. Jenis kayu dan bambu ada beragam, masing-masing jenis ada peruntukkannya sendiri. Berikut gambaran bahan-bahan yang digunakan dan yang harus dipersiapkan oleh pemilik rumah:
(1) Bahan untuk fondasi (tekian)

Bagian yang pertama kali dibuat adalah tekian. Tekian menyerupai fondasi namun keberadaannya di atas tanah, sedang fondasi keberadaannya di dalam tanah. Tekian dibuat dengan bata yang berbahan tanah, dedek kulit padi yang lebih halus dibandingkan dengan sekam, diperoleh dari hasil penggilingan atau penumbukan yang kedua', dan air. Ketiga bahan tersebut dicampur, dibentuk, lalu dibakar. Dedek diambil dari tempat menumbuk padi.

\section{(2) Bahan untuk kerangka}

Kerangka rumah terdiri atas saka 'tiang', pengeret dan penglari, sunan, rambat tikus, usuk, reng, siku-siku, kudakuda, dan jure.

Saka 'tiang' rumah, bisa menggunakan kayu jati, kayu banujan, kayu johar, dan kayu pohon kelapa. Fungsi saka adalah untuk menyangga bangunan. Tidak heran bagi mereka yang mampu secara ekonomi, mereka akan memilih menggunakan kayu jati untuk saka-nya supaya kuat.

\section{Gbr. 3 Saka}

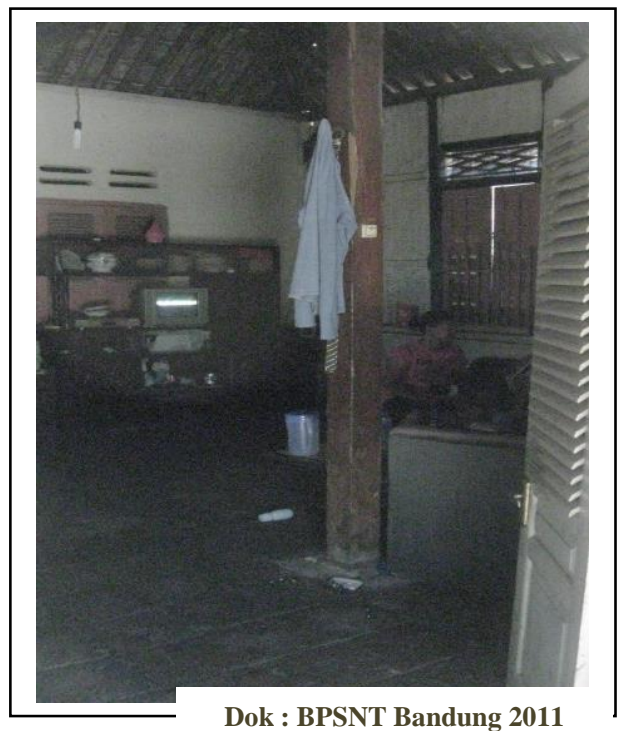

Pengeret dan penglarl, selain dari kayu jati, dapat menggunakan kayu banujan atau johar. Fungsinya untuk menghubungkan antara saka dengan saka. 
Gbr. 4 Pengeret

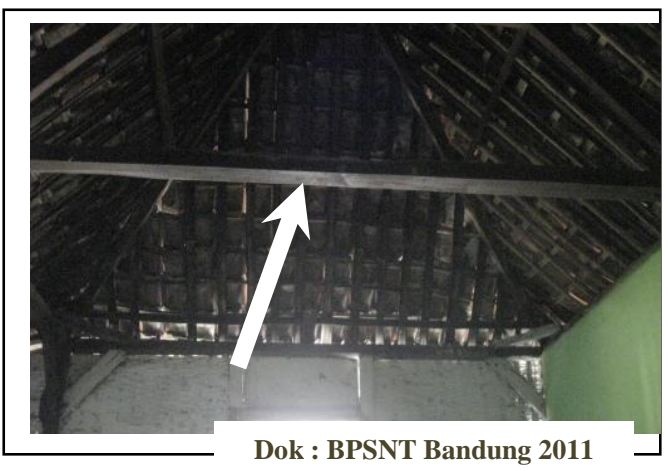

Gbr. 5 Penglari

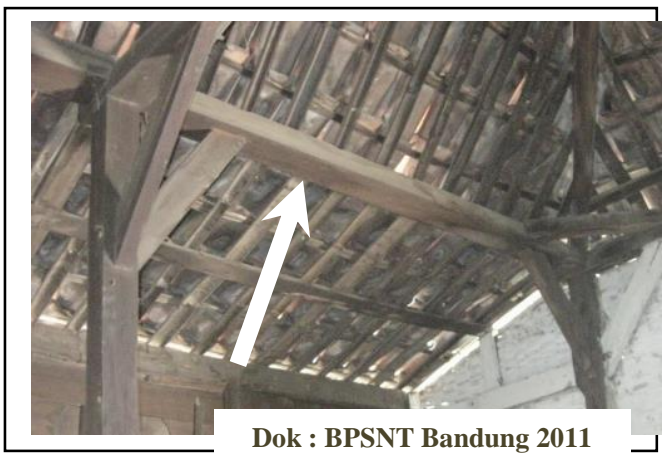

Sunan, biasa menggunakan kayu jati. Pada 1 sunan terdapat 8 saka. Jumlah angka 9 melambangkan jumlah Wali Sanga.

\section{Gbr. 6 Sunan}

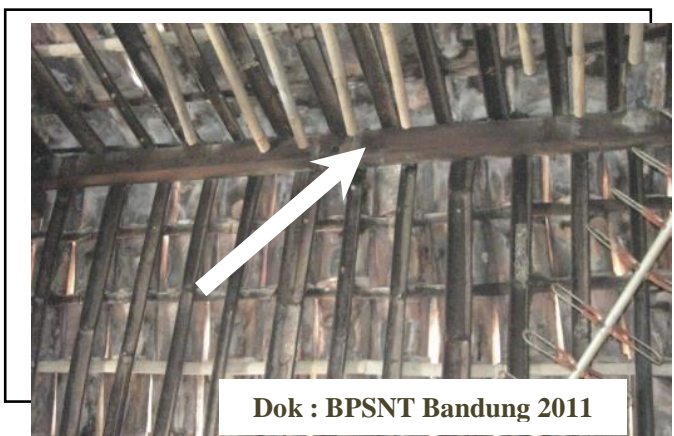

Rambat tikus, menggunakan kayu lokal. Fungsi rambat tikus untuk menahan kayu, bambu, dan genting yang ada di atasnya. Disebut rambat tikus karena di kayu ini tikus-tikus sering merambat.
Gbr.7 Rambat Tikus

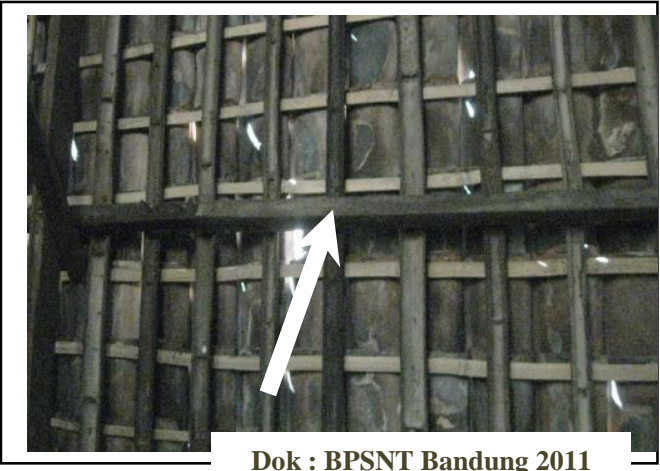

Reng, menggunakan bambu yang besar lalu dibelah menjadi 8 .

Gbr. 8 Reng

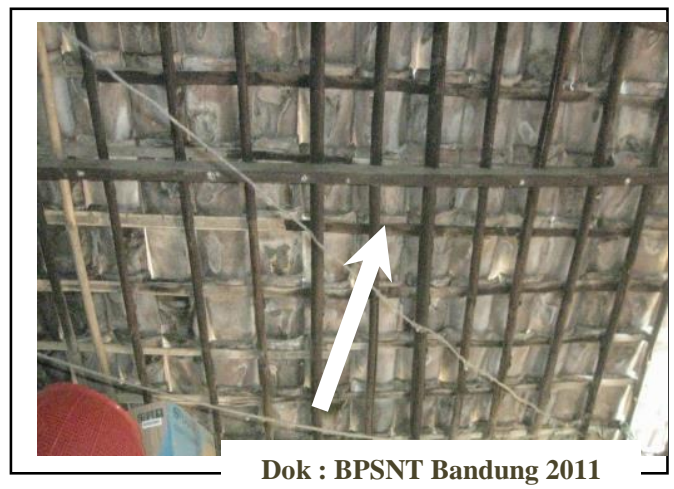

Usuk, menggunakan kayu turi atau juga bambu. Kayunya adalah kayu yang kecil dan masih dalam bentuk gelondongan. Apabila menggunakan bambu, yang digunakan adalah bambu yang kecil dan masih dalam bentuk batangan.

Gbr. 9 Usuk

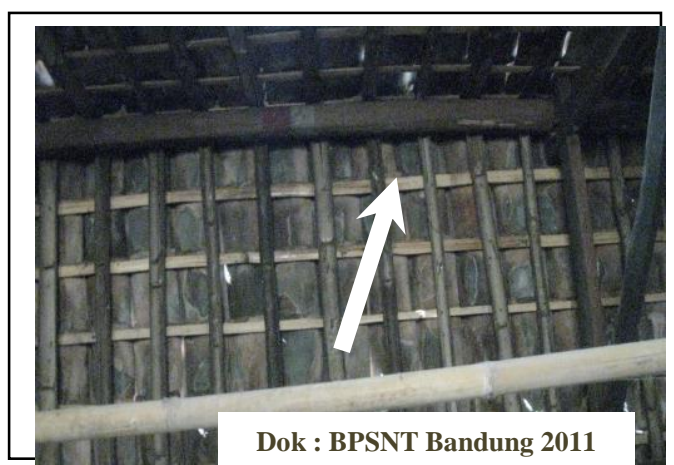




\section{Gbr. 10 Siku-siku}

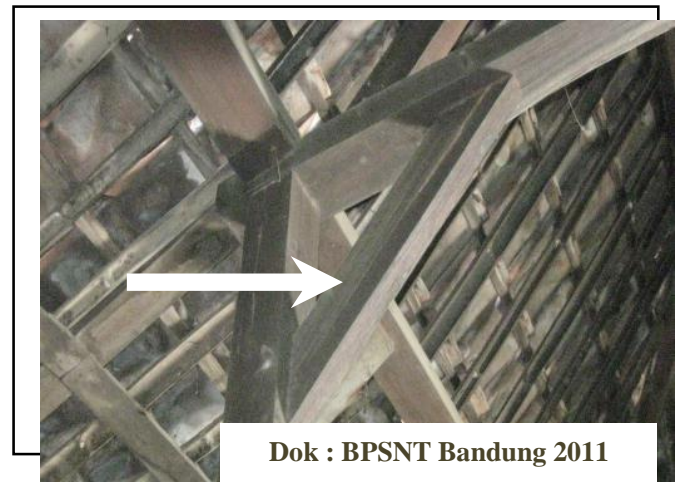

Gbr. 11 Kuda-kuda

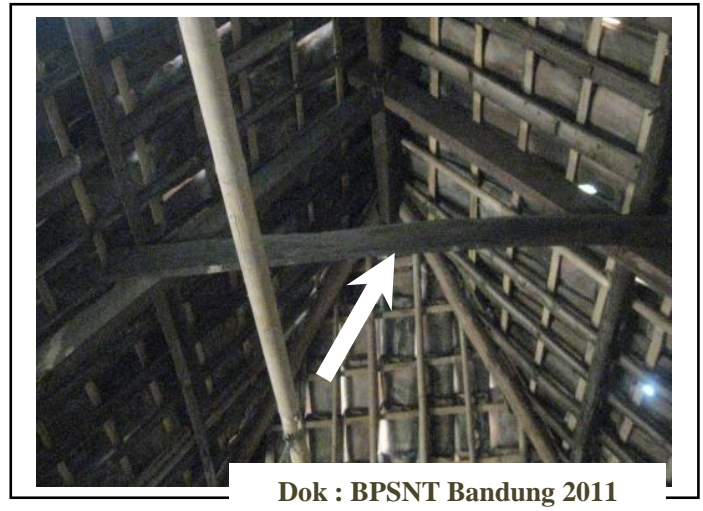

Gbr. 12 Jure

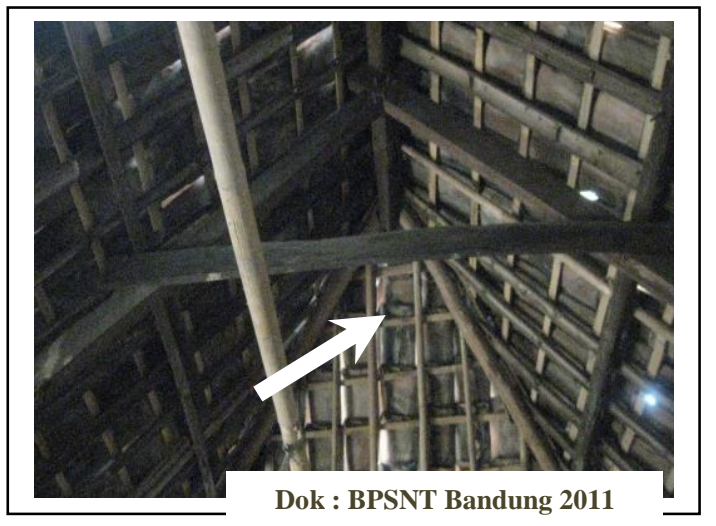

(3) Bahan untuk gribik 'dinding berupa anyaman bambu'

Gribik rumah, menggunakan pring 'bambu' apus. Baik kulit atau isi bambu, keduanya sama-sama bisa digunakan. Hanya saja bagian kulitnya lebih kuat dibandingkan isinya. Bambu yang digunakan sebagai gribik terlebih dahulu dianyam oleh tukang anyam. Tukang ini biasanya juga menger- jakan anyaman untuk rajeg 'pagar' rumah. Umumnya gribik berwarna coklat (warna asli bambu) dan putih yang diperoleh dengan cara mengapur.

\section{Gbr. 13 Gribik sebagai dinding rumah}

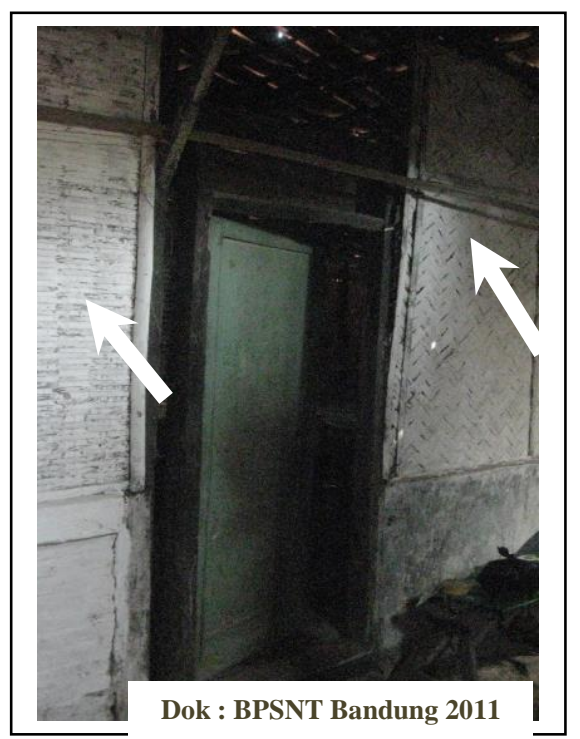

(4) Bahan untuk lawang 'pintu', gendela 'jendela', roji-roji 'tralis', dan angin-angin 'lubang angin'

Lawang 'pintu', gendela 'jendela', roji-roji 'tralis', dan angin-angin 'lubang angin/fentilasi', bisa menggunakan kayu lokal atau kayu jati. Keempat bagian badan bangunan itu harus kuat sebab berhubungan langsung dengan rumah bagian luar. Bagi mereka yang mampu, akan menggunakan kayu jati.

Model pintu pada tiap-tiap rumah tidak sama. Ada yang berdaun pintu dua, ada pula yang berdaun pintu satu. Pintu berdaun dua pada umumnya terdapat pada rumah limasan yang melebar ke samping, sedang pintu berdaun satu terdapat pada rumah srotongan yang memanjang ke belakang.

Selain itu, ada pula yang disebut dengan lawang jero 'pintu bagian dalam' dan lawang jaba 'pintu bagian luar. Tidak semua rumah menggunakan kedua jenis pintu itu sekaligus. Bagi rumah yang berpintu dua, penggunaan lawang jaba dimaksudkan agar penghuni rumah dapat leluasa mendapatkan udara sementara keamanan rumah tetap terjaga. 
Peletakan pintu keluar rumah dengan pintu yang ada di dalam rumah lurus sejajar. Sebagian masyarakat percaya kalau letak pintu seperti itu maka rizki penghuni rumah akan lurus lancar, tidak ada hambatan.

Gbr. 14 Lawang Jaba dan Lawang Jero

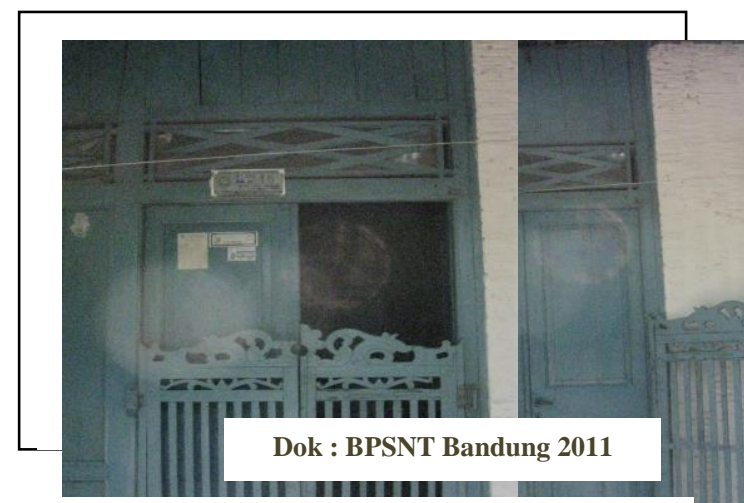

Gbr. 15 Pintu keluar dan masuk rumah lurus dengan pintu di dalam rumah

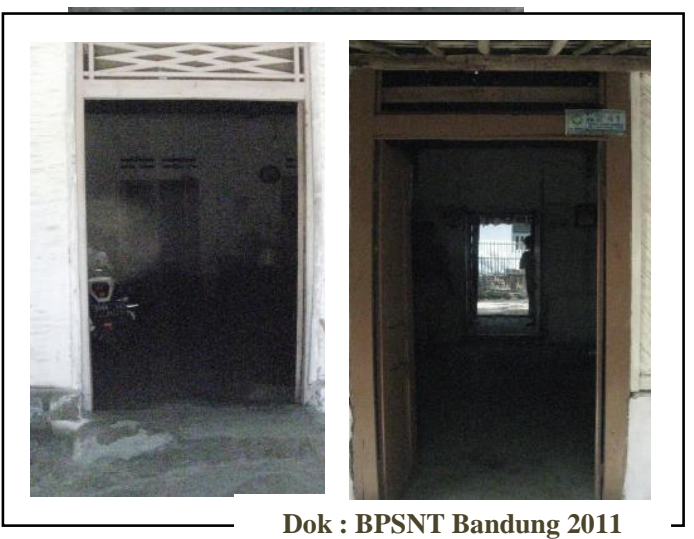

Gbr. 16 Angin-angin

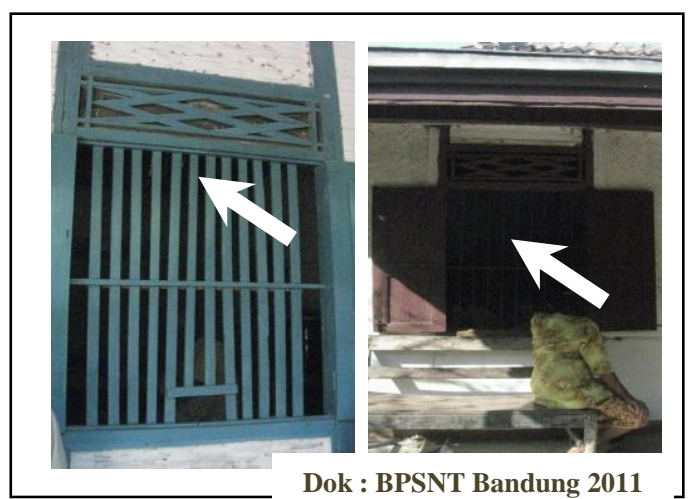

Gbr. 17 Roji-roji

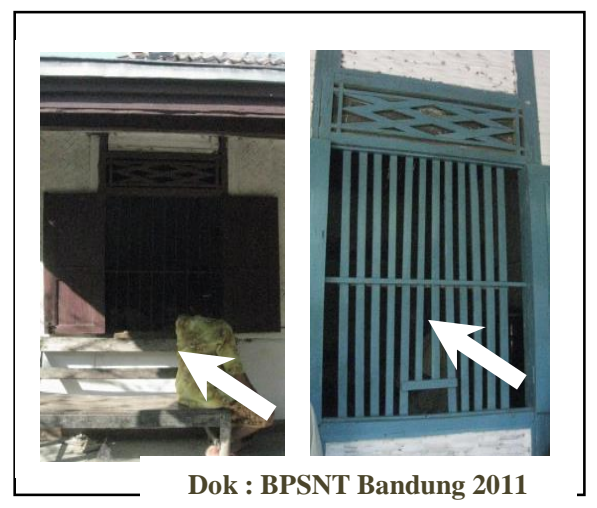

(5) Bahan untuk atap

Awalnya, atap rumah menggunakan welit 'daun kelapa'. Selanjutnya atap rumah berubah menggunakan genting. Genting diterapkan pada bagian bangunan inti, yakni mulai dari ruang blandongan dan seterusnya. Sedang bagian depan rumah atau emper 'teras', ada yang beratapkan seng atau asbes.

\section{(6) Bahan untuk lantai}

Ada dua jenis lantai pada rumah Junti. Ada lantai dari bata merah dan ada dari bahan untuk membuat bata merah. Bata merah dibuat dari campuran antara dedek, tanah, dan air. Ketiga bahan tersebut dibentuk, dijemur, lalu dibakar. Apabila menggunakan bahan bata merah maka keempat bahan yaitu dedek, tanah, abu dapur, dan air dicampur lalu disiramkan ke atas tanah yang akan dilantai, kemudian dilus 'dihaluskan menggunakan telapak tangan'. Rumah yang berlantai bata menandai kalau si empunya adalah orang yang mampu.

Gbr. 18 Jenis lantai

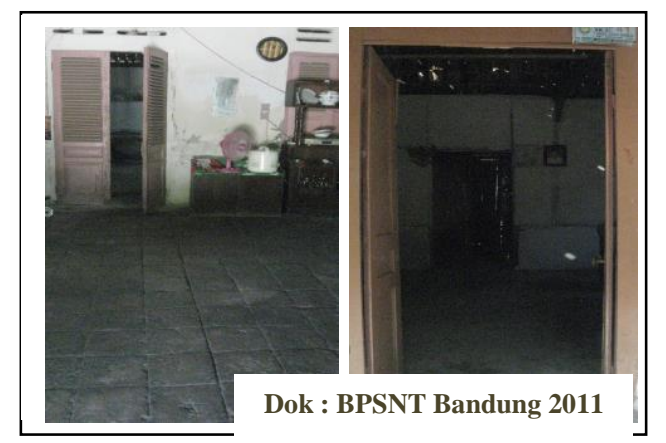


Perolehan bahan bangunan bisa beragam. Kayu bisa diperoleh dengan membeli atau mengambil dari kebun sendiri. Bagi yang membeli, mereka membeli dari lingkungan sekitar. Adapun genting, dibeli dari kecamatan terdekat.

\section{b) Tahap Pelaksanaan}

Manakala semua bahan yang dibutuhkan untuk membangun rumah sudah siap, maka dipanggillah tukang bangunan yang jauh hari sudah dihubungi oleh pemilik rumah. Tukang tersebut datang dengan membawa peralatan yang akan digunakan untuk membangun rumah. Biasanya, seorang tukang bangunan memiliki seperangkat alat bangunan secara lengkap. Zaman dulu, alat itu ditempatkan dalam sebuah peti. Isinya di antaranya adalah: suguh, tatah, serok, gergaji, kampak, dan catut. Zaman sekarang, tukang bangunan membawa alat bangunannya dengan kandet 'karung bekas beras/terigu'.

Membangun rumah ada beberapa tahap pekerjaan, sebagai berikut:

- Memotong kayu, menjemur kayu, ngungkum 'merendam' kayu di sungai, kayu disugu 'dihaluskan', dibobok 'dilubangi tanpa alat', dibor.

- Membuat saka 'tiang', sunan, pengeret, penglari, rambat tikus, kuda-kuda, usuk, reng, kuda-kuda, dan siku-siku.

- Pagar bambu dianyam oleh tukang anyaman.

- Neki 'membuat fondasi di atas tanah dan batas-batas ruang dengan tali'.

- Memasang bata, saka 'tiang', rangka atap, dan atap.

- Membuat gribik, pasang gribik.

- Memasang bata untuk lantai atau membuat lantai.

Tenaga inti untuk membangun rumah adalah tukang bangunan dan tukang pagar (tukang membuat anyaman). Selebihnya adalah pemilik rumah dan tetangga sekitar (laki-laki dewasa). Tukang bangunan berasal dari satu desa, tukang tersebut turuntemurun dari tukang-tukang sebelumnya. Membangun rumah biasanya memerlukan waktu sekitar 20 hari. Pada 2 sampai 3 hari pertama, tetangga akan turut membantu secara sukarela.

Pada tahap pelaksanaan pendirian rumah, ada beberapa upacara yang dilaksanakan oleh pemilik rumah. Upacaraupacara tersebut sebagai berikut:

- Slametan neki/sajenan, upacara ini merupakan upacara yang dilakukan saat membuat tekian 'fondasi'. Pada upacara ini, si empunya rumah membuat sesaji berupa nasi putih yang dibentuk kerucut (tumpeng) dan diwadahi dalam sebuah tampah. Di sekeliling tumpeng diletakkan ikan gesek, air putih dalam kendi kecil, kembang tujuh rupa, rokok, dan kopi. Sesaji ini didoai oleh tokoh adat dan sesudahnya diletakkan di samping rumah. Selanjutnya acara doa dan makan bersama yang diikuti oleh para tetangga.

- Ngunjukna usunan, adalah upacara menaikkan sunan. Sebelum sunan dinaikkan, kayu untuk sunan terlebih dahulu dicuci dengan air kembang atau jenis wewangian lainnya. Maksudnya adalah agar penghuni rumah selalu harum namanya. Ketika menaikkan sunan dibarengi dengan azan dan qomat. Manakala sunan sudah naik, diletakkan kelengkapan berupa bendera merah putih yang diartikan sebagai wujud kemerdekaan suatu bangsa. Kembang tujuh rupa, angka tujuh diartikan sebagai jumlah hari dalam satu minggu yang harus diisi dengan kegiatan yang positif. Payung, diartikan bahwa rumah yang akan ditempati kelak dapat melindungi penghuninya dari marabahaya sekaligus bisa memberi kenyamanan bagi yang menghuninya. Kalau ada uang, si empunya rumah biasa menyisipkan emas setengah gram di dalam bendera. Emas diartikan penghuni rumah selalu dalam keadaan berlimpah rizki. Di setiap sudut rumah diletakkan sesaji tolak bala di antaranya berupa kembang jambe, beringin, dan pringgading.

Seusai rumah berdiri, dilakukan bersih-bersih rumah. Bukan saja dimaksudkan untuk membersihkan rumah dari debu bangunan, melainkan juga membersihkan dari hal-hal yang "tidak tampak". 


\section{Fungsi Bagian-bagian Bangunan}

Kalenan 'selokan' berfungsi untuk saluran air, sedang buk digunakan untuk duduk-duduk santai yang biasanya berlangsung sore hari atau di saat santai.

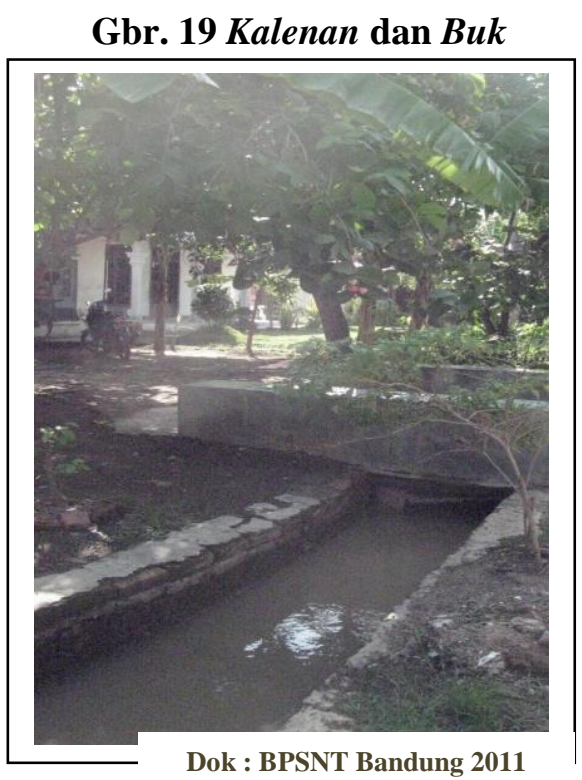

Gbr. 20 Jobong

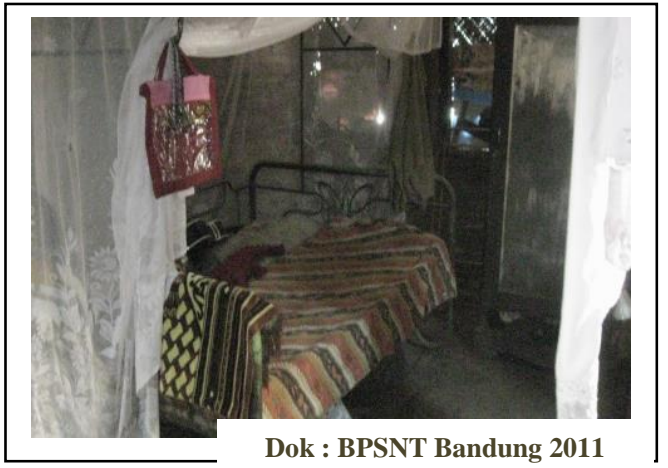

Pawon digunakan untuk kegiatan masak-memasak, sedangkan kulah untuk mandi, buang air besar, dan mencuci pakaian. Konon kalau pawon banyak abunya menandakan si empunya rumah banyak sodakoh, sering memasak dan mengirim kepada tetangga.
Gbr. 21 Pawon dan Kulah

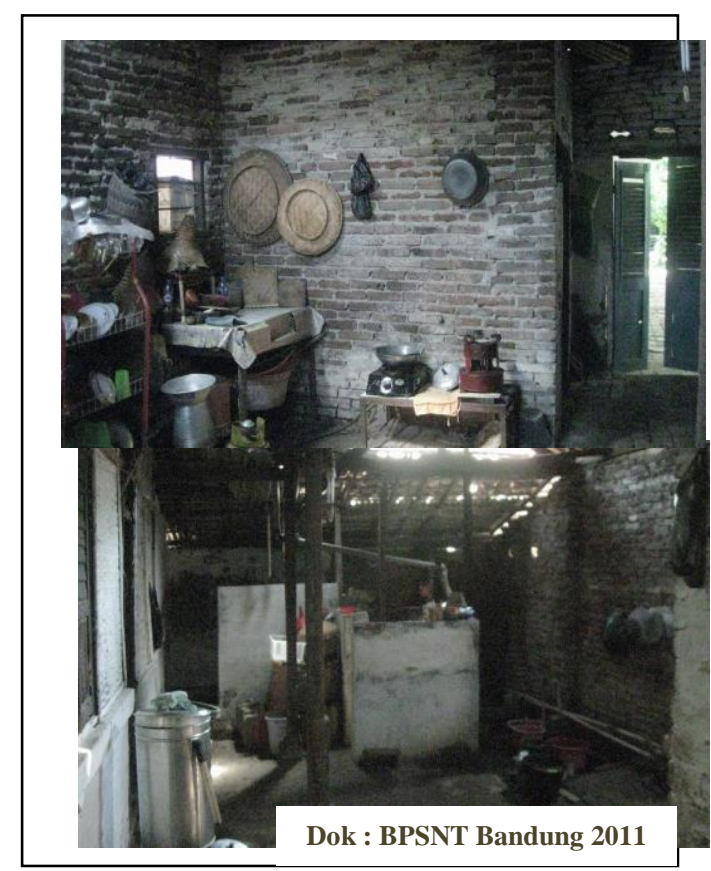

Latar, pada masyarakat tani latar digunakan sebagai tempat menjemur padi, sedang pada masyarakat nontani digunakan untuk menanam aneka pohon buah.

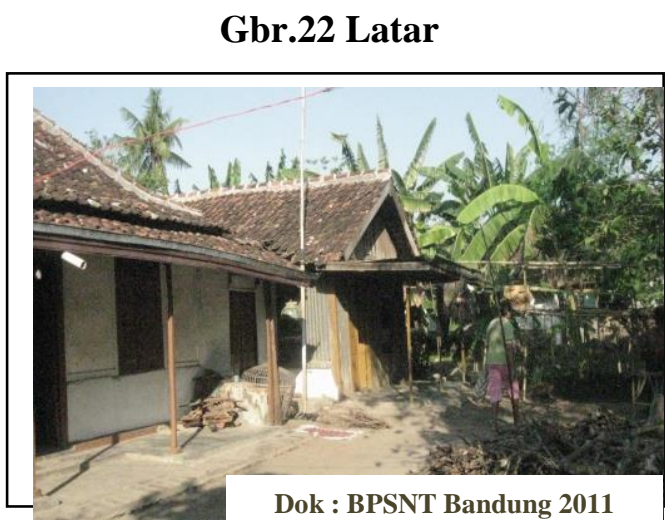

Ambal 'tangga' ke emper, gunanya untuk menahan air kalau terjadi hujan, agar air tidak masuk ke rumah. 
Gbr. 23 Ambal

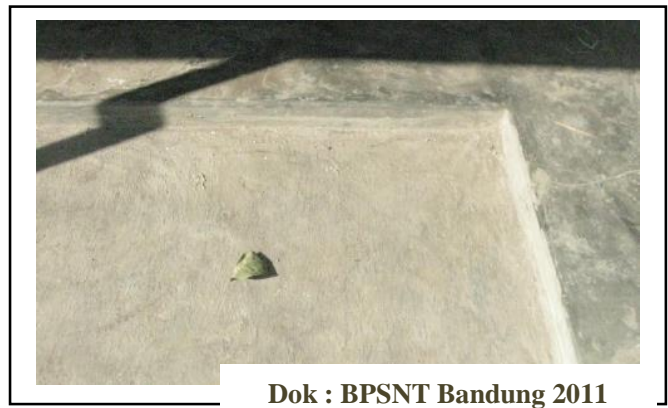

Emper 'teras' digunakan untuk midang 'duduk-duduk santai'.

\section{Gbr. 24 Emper}

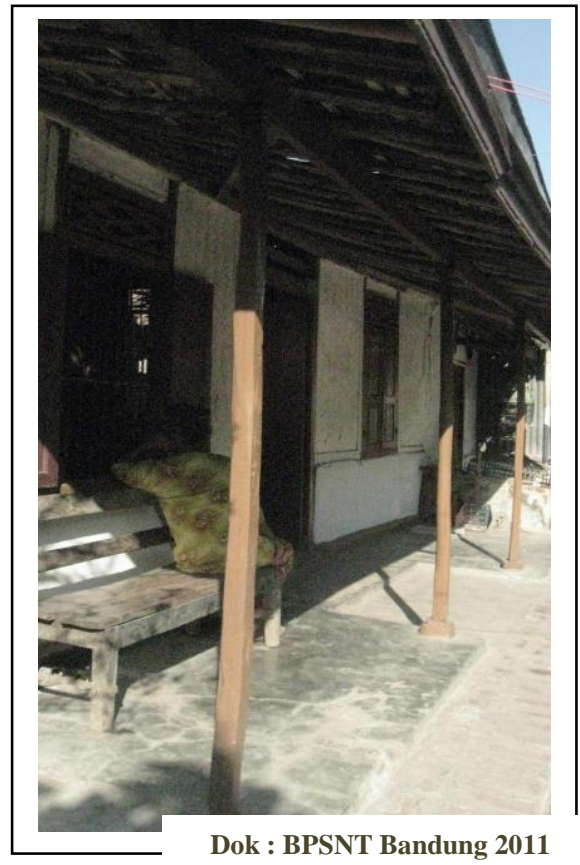

Blandongan merupakan ruang tamu. Tempat duduknya menggunakan dingklik 'bangku' atau gelaran 'menggelar tikar yang terbuat dari wlengi yakni rumput yang besar-besar dan tinggi'. Pada salah satu sudut blandongan acapkali diletakkan sebuah tempat tidur yang digunakan orang tua untuk sekadar tidur-tiduran di siang hari. Pada rumah ajengan, sebagian ruang blandongan ditinggikan dengan semen, digunakan untuk mengaji.
Gbr. 25 Blandongan

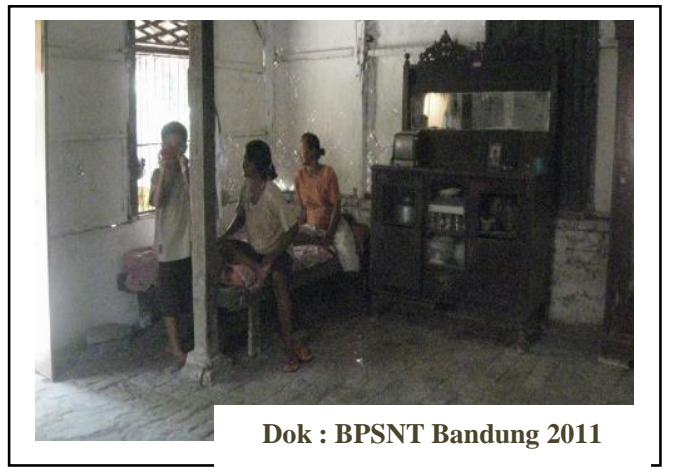

Ruang terbuka di belakang rumah disebut grimah: guri omah 'belakang rumah', sedang antara rumah bagian depan dengan belakang disebut longkrang.

Gbr. 26 Grimah

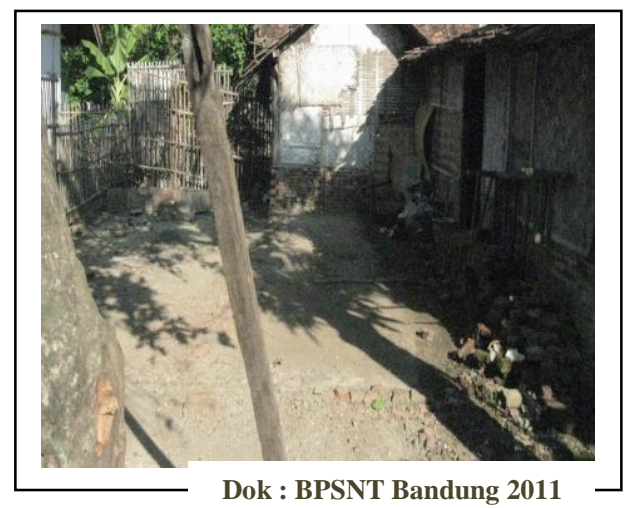

Gbr. 27 Model-model Rumah

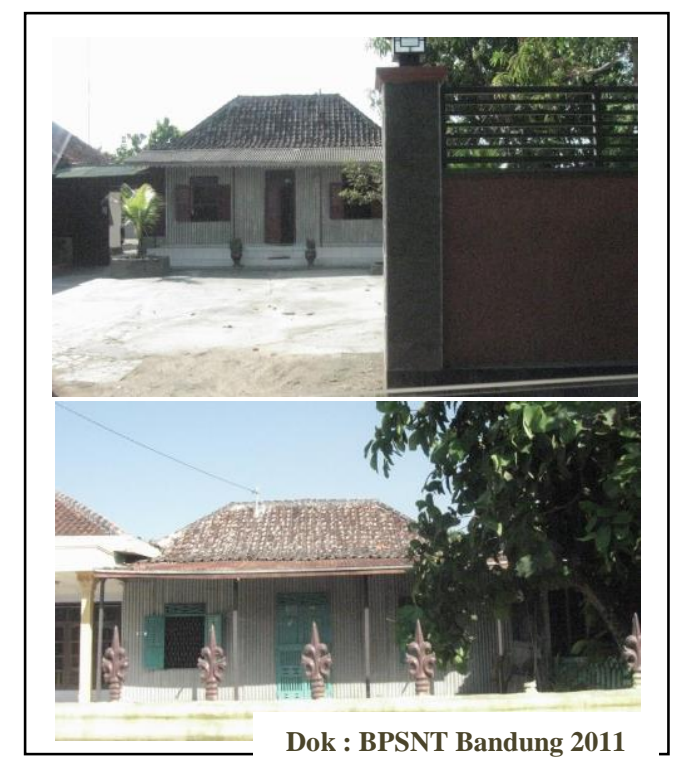




\section{Ragam Hias}

Rumah Junti tidak banyak menggunakan ragam hias, terkecuali pada bagian angin-angin. Motifnya serupa dengan motif yang terdapat pada batik Indramayu dan Cirebon. Pada lembaran batik, motif tersebut selain menjadi motif untuk selembar kain secara menyeluruh, juga digunakan untuk bagian tumpal saja.

Pada batik, motif-motif serupa itu bernama motif banji, geometris, dan belah ketupat. Ragam banji banyak menghias batik dari pantai utara Jawa (Suwati Kartiwa, 2005:3-4). Motif belah ketupat terdapat pada kain sarung batik pesisiran yang melengkapi motif tumpal pada bagian kepala kain.

\section{PENUTUP}

Arsitektur merupakan aspek visual dari kebudayaan dan arsitektur tradisional merupakan aspek visual dari kebudayaan lokal. Tersimpulkan bahwa rumah Junti, merupakan rumah tradisional yang berada di Desa Juntikebon khususnya, dan Kecamatan Juntinyuat pada umumnya. Ciri-ciri ketradisionalan pada rumah Junti tampak dari bahan rumah, asal-usul bahan, tenaga kerja, cara pembuatan, makna yang melekat pada unsur bangunan, dan upacara yang menyertai pendirian rumah. Selain itu, bentuk, struktur, fungsi, ragam hias, dan cara membangun diwariskan dari generasi ke generasi. Pewarisan seperti itu menggambarkan adanya suatu pola yang tertentu dan baku serta yang telah berlangsung dalam jangka waktu dan keteraturan tertentu.

Rumah Junti berbahan kayu dan bambu yang diperoleh dari lingkungan sekitar, dibangun oleh "tenaga ahli" dibarengi asas gotong-royong warga, cara pembuatan rumah secara manual, ada makna yang melekat di beberapa bagian unsur bangunan, dan melakukan ritual upacara demi mendapatkan keselamatan. Rumah Junti merupakan rumah yang dibangun dengan berasas pada keyakinan agama dan kepercayaan setempat; diadaptasikan dengan iklim, lingkungan alam setempat, dan bahan bangunan; selain itu bentuk atap dominan atau menonjol. Tampak bahwa orientasi religi mendapat tempat dalam arsitektur tradisional.

Sebagaimana karya budaya daerah pesisir, ragam hias pada rumah Junti tidak banyak muatan makna. Namun demikian dari ragam hiasnya yang ada ditengarai tidak lepas dari pengaruh budaya Cina. Hal ini terlihat dari adanya kesamaan antara ragam hias rumah dengan ragam hias batik Dermayon yang mendapat pengaruh dari Cina. Pengaruh ini diperkuat juga dari adanya kisah masuknya Cina ke Juntinyuat.

Terkait dengan keberadaan rumah Junti sekarang ini, menunjukkan fenomena bahwa peningkatan ekonomi yang terjadi di Desa Juntikebon berbanding terbalik dengan keberadaan rumah Junti. Semakin meningkat kemampuan ekonomi masyarakatnya maka keberadaan rumah Junti semakin berkurang. Hal ini terjadi oleh karena peningkatan ekonomi cenderung menggeser dari kiblat ketimuran ke Barat, dari rumah tradisional ke rumah modern. Tampaknya diperlukan kesadaran budaya bagi masyarakat lokal untuk mempertahankannya.

Saran yang bisa disampaikan untuk kondisi rumah Junti saat ini, yakni: Pertama, pemerintah daerah setempat dapat menghimbau agar bangunan perkantoran, sekolah, dan pelayanan publik yang ada di wilayah Kecamatan Juntinyuat dibangun dengan "menggunakan" model rumah Junti. Setidaknya, atap limasan yang merupakan ciri dominan dari asitektur rumah Junti bisa diterapkan pada bangunan publik selain bangunan rumah tinggal. Kedua, membuat "album" budaya dengan cara membuat miniatur rumah Junti, yang harus dipajang di kantor-kantor, sekolah, dan bangunan publik yang ada di Kecamatan Juntinyuat. Media lain untuk album budaya tentang rumah Junti juga dapat diwujudkan melalui motif tenun yang diproduksi di Juntinyuat dan batik Dermayon. Ketiga, menjadikan miniatur rumah Junti sebagai cinderamata dari pihak pemerintah daerah, khususnya wilayah Kecamatan Juntinyuat, kepada para tamunya. 
DAFTAR SUMBER

Frick, Heinz. 1996.

Arsitektur dan Lingkungan. Yogyakarta: Kanisius.

Herlinawati, Lina. 2010.

Kajian Nilai Budaya pada Arsitektur Tradisional di Giri Jaya Padepokan Kab. Sukabumi Prov. Jawa Barat. BPSNT

Bandung.

Kartiwa, Suwati dan Arifin, Zaenal, 2005

Fungsi dan Makna Kain Tradisional yang Dipengaruhi Budaya China. Makalah dalam Seminar Tekstil Tradisional yang Dipengaruhi oleh Budaya Cina. Jakarta: Direktorat Tradisi.

Purwanto, Semiarto Aji. 2009. Makna dan Fungsi Arsitektur Tradisional. Makalah dalam Kegiatan Bimbingan Teknis Inventarisasi Arsitektur Tradisional.

Purwestri, Nadia. 2009. Arsitektur Tradisional Gambaran Umum. Pusat Dokumentasi Arsitektur. Makalah dalam Kegiatan Bimbingan Teknis Inventarisasi Arsitektur Tradisional.

2009.

Abstraksi Tradisi Arsitektur Nusantara. Makalah dalam Kegiatan Bimbingan Teknis
Inventarisasi Arsitektur Tradisional. Direktorat Tradisi Ditjen NBSF. Departemen Kebudayaan dan Pariwisata.

2009.

Pedoman Pelaksanaan

Inventarisasi Arsitektur

Tradisional. Makalah dalam

Kegiatan Bimbingan Teknis

Inventarisasi Arsitektur

Tradisional. Direktorat Tradisi

Ditjen NBSF. Departemen

Kebudayaan dan Pariwisata.

Purnama, Yuzar dkk. 2004

Budaya Tradisional pada Masyarakat Indramayu. Bandung: BKSNT.

Wiryo Hadinagoro, Daud. 2005

Aspek Politis pada Perkembangan tekstil Tradisional yang

Dipengaruhi Budaya Cina. Makalah dalam Seminar Tekstil Tradisional yang Dipengaruhi oleh Budaya Cina. Jakarta: Direktorat Tradisi. 